\title{
RANCANGAN APLIKASI SMS GATEWAY UNTUK PEMESANAN PENDAFTARAN SERVICE SEPEDA MOTOR DI AHASS XYZ
}

\author{
Ade Kurnia Solihin \\ Program Studi Informatika, Universitas Indraprasta PGRI \\ adekurniasolihin@gmail.com
}

\begin{abstract}
Abstrak
Astra Honda Authorized Service Station xyz (AHASS xyz) adalah perusahaan yang bergerak dalam penyedia jasa perawatan dan penjualan spare parts khusus untuk merek sepeda motor honda. Sebagai perusahaan yang bergerak dalam bidang jasa, kualitas pelayanan menjadi hal yang sangat penting untuk dijaga dan ditingkatkan. Untuk mendapatkan pelayanan service sepeda motor di astra honda authorized service station (AHASS), AHASS merupakan bengkel resmi sepeda motor khusus merek honda yang melayani perawatan, penjualan sepeda motor dan penjualan sparepart khusus sepeda motor merek honda. Di AHASS XYZ pelanggan harus antri cukup lama karena banyaknya pelanggan yang juga ingin mendapatkan pelayanan service sepeda motor, kondisi ini yang membuat pelanggan tidak nyaman karena banyak waktu terbuang dengan sia-sia untuk menunggu antrian service. Tujuan dari penelitian ini adalah mengurangi waktu tunggu calon pelanggan pada saat akan melakukan perawatan sepeda motor di AHASS. Dalam perancangan sistem ini metode pengumpulan data yang digunakan studi pustaka, wawancara dan observasi. Metode pengembangan sistem yang digunakan, menggunakan metode waterfall, Bahasa pemrograman yang yang digunakan dalam perancangan adalah PHP serta menggunakan software bantu Gammu dan database menggunakan MySQL. Berdasarkan penelitian yang dilakukan maka perancangan sistem aplikasi SMS Gateway untuk pemesanan pendaftaran service sepeda motor di AHASS. Dapat di jadikan solusi yang baik untuk mengatasi permasalahan antrian dan waktu tunggu yang terjadi di AHASS XYZ.
\end{abstract}

Kata Kunci : Waterfall, AHASS, SMS Gateway, Gammu, PHP, MySQL.

\begin{abstract}
Astra Honda Authorized Service Station xyz (AHASS xyz) is a company engaged in the service providers maintenance and sale of spare parts specific to honda motorcycle brand. As a company engaged in the field of services, quality of service is very important to be kept and improved. To get the service of the astra's motorcycle service honda authorized service station (AHASS), is the official workshop AHASS motorcycles honda brand that caters to special care, motorcycle sales and sales of motorcycle-specific spare parts brands Honda. At AHASS xyz customers have to stand in line for quite a while because of the many customers who also want to get service service motorcycles, these conditions that make customers uncomfortable because a lot of time wasted in vain for wait queue service. The purpose of this research is to reduce the waiting time a prospect at the moment will be doing maintenance on a motorcycle at AHASS. In this system the design of the data collection method that is used for library studies, interviews and observations. Systems development methods are used, use the method waterfall, the programming language that is used in the design is the PHP and using software extension gammu and database using MySQL. Based on research done then SMS Gateway application system design for booking registration service AHASS motorcycle. You can make a good solution to overcome the problem of queues and waiting times that occur in AHASS xyz.
\end{abstract}

Keywords: Waterfall, AHASS, SMS Gateway, Gammu, PHP, MySQL.

\section{PENDAHULUAN}

Perkembangan otomotif di Indonesia pada tahun ke tahun mengalami kemajuan yang pesat. Semakin banyaknya masyarakat Indonesia membeli motor, menjadikan peluang-peluang usaha baru seperti penyediaan jasa perawatan motor (bengkel motor). Pelayanan dan kepuasaan pelanggan merupakan inti dari usaha sebuah jasa bengkel sepeda motor, 
pelayanan yang prima membuat pelanggan merasa puas atas kinerja bengkel motor.

Perkembangan otomotif mengalami kemajuan yang sangat pesat di bidang teknologi, terutama teknologi informasi komputer berpengaruh untuk mendorong munculnya inovasi baru dalam penyajian informasi untuk memenuhi kebutuhan informasi. Salah satu inovasi dalam bidang teknologi informasi adalah SMS Gateway.

Short Message Service Gateway yang kemudian di singkat menjadi SMS Gateway. SMS adalah kemampuan untuk mengirim dan menerima pesan dalam bentuk teks dari dan kepada perangkat mobile. SMS Gateway sendiri memiliki pengertian sebuah gerbang yang menghubungkan komunikasi komputer dengan pengirim pesan melalui SMS [4].

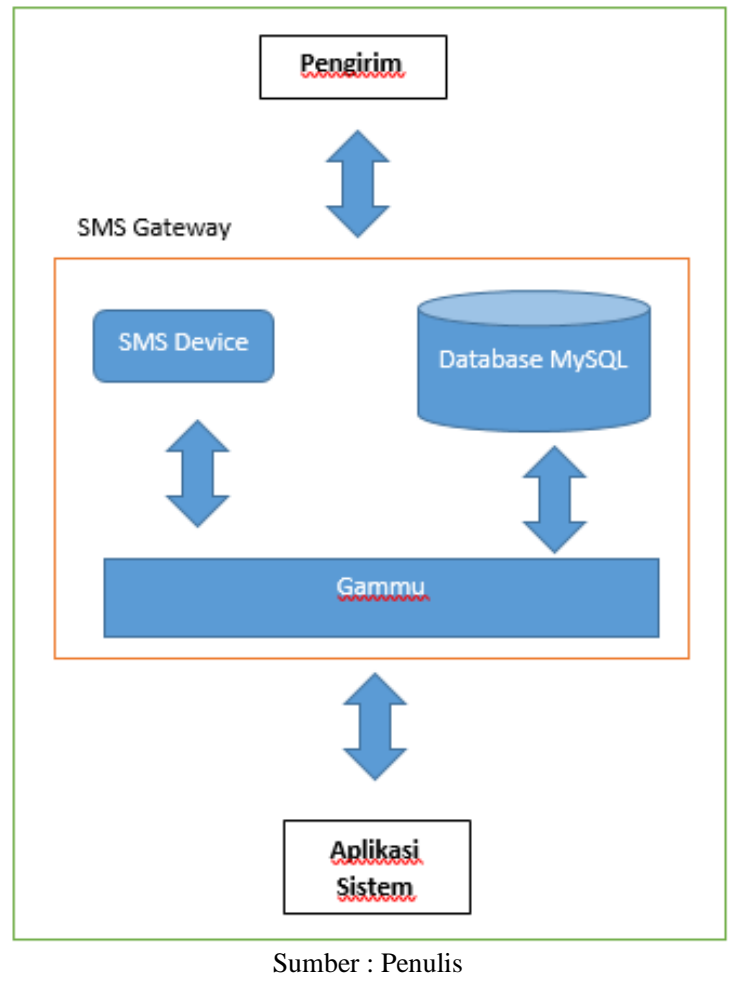

\section{Gambar 1. Proses SMS Gateway}

SMS Gateway banyak diterapkan untuk sarana informasi dan promosi-promosi dalam bidang jasa maupun barang disebuah perusahaan. Astra Honda Authorized Service Station XYZ ( AHASS
XYZ) adalah perusahaan yang bergerak dalam penyedia jasa perawatan dan penjualan Spare Parts khusus untuk merek sepeda motor Honda atau Bengkel resmi Honda, Lebih di kenal dengan nama AHASS. Sistem informasi alur pelayanan pelanggan yang di terapkan di bengkel AHASS XYZ secara berurutan dapat dilihat dalam gambar dibawah ini.

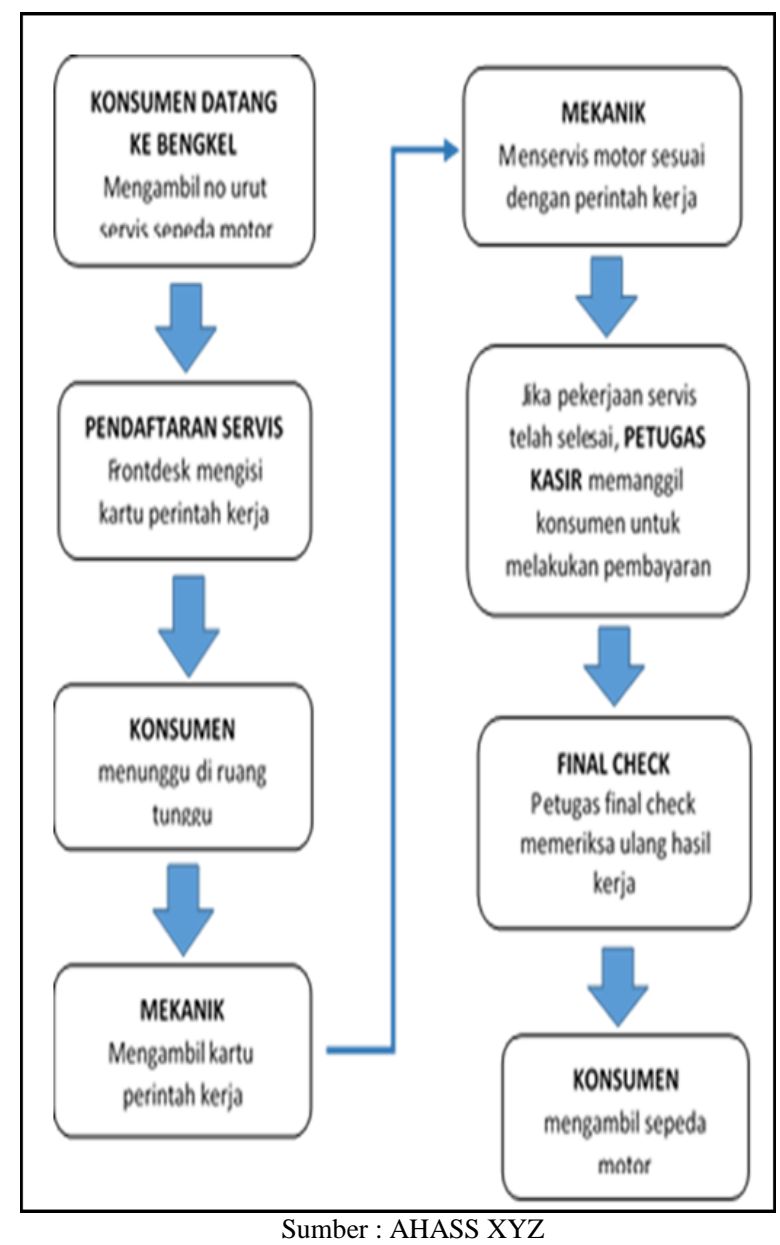

Gambar 2. Alur Kerja AHASS

Kekurangan dari sistem informasi alur kerja AHASS adalah pelanggan membutuhkan waktu tunggu yang lama jika situasi dan kondisi AHASS sedang dalam keadaan banyak pelanggan/ramai yang melakukan perawatan sepeda motor, dan terjadi antrian untuk mendapatkan perawatan sepeda motor. 
SMS Gateway merupakan gerbang komunikasi antara aplikasi yang dibuat dengan device modem SMS, Aplikasi yang menggunakan fitur ini biasanya untuk mengirimkan pesan secara otomatis dengan fitur autoreply sehingga memudahkan tujuan dari penggunaan aplikasi tersebut baik untuk pendaftaran, pemesanan, maupun notifikasi secara otomatis pesan yang dikirim pun dapat dikirim secara massal dalam jumlah ribuan tergantung device modem yang digunakan.. Dengan SMS kita dapat menyebarkan pesan ke banyak nomor sekaligus secara otomatis dan cepat[1].

PHP merupakan bahasa Server Side Scripting, secara prinsip Server akan bekerja apabila ada permintaan dari client, Client tersebut akan dikirimkan ke Server, kemudian Server akan mengembalikan pada halaman sesuai instruksi yang diminta [2].

MySQL adalah sebuah database manajemen system (DBMS) popular yang memiliki fungsi sebagai relational database manajemen system (RDBMS). Selain itu MySQL merupakan suatu aplikasi tidak berbayar / free license yang sifatnya open source. Kelebihan server basis data MySQL memiliki kinerja sangat cepat, reliable, dan mudah untuk digunakan serta bekerja dengan arsitektur client server atau embedded systems [3].

Gammu adalah service yang disediakan untuk membangun aplikasi yang berbasis SMS gateway. Selain mudah, aplikasi SMS gateway dengan gammu adalah free license. Mekanisme kerja dari gатти dapat sebagai aplikasi dan sebagai deamon. Gaтmu sebagai aplikasi running ketika perintah gammu dijalankan pada lingkungan shell beserta perintahnya disertakan sesuai dengan tujuan yang diinginkan. Sedangkan sebagai deamon, gammu berfungsi ketika dijalankannya perintah smsd pada shell. Pada dasarnya prinsipnya cara kerja gammu yaitu menghubungkan modem / handphone dengan PC dan aplikasi yang dibuat unutk merima atau mengirimkan SMS. SMS yang diterima di modem / handphone akan diambil oleh gammu untuk dipindahkan ke dalam database yang telah diatur sebelumnya [4].

\section{METODE PENELITIAN}

Secara garis besar, penelitian ini melalui tiga tahapan yaitu studi pustaka, wawancara dan observasi, tahapan perancangan aplikasi menggunakan bahasa pemrogaman PHP dan MySQ1.

Berdasarkan data wawancara dan observasi terhadap pelanggan dan karyawan Astra Honda Authorized service Station xyz lebih di kenal AHASS bengkel resmi sepeda motor honda. dilapangan didapatkan hasil bahwa banyak pelanggan yang merasa bosan karena lama menunggu untuk mendapatkan pelayanan service sepeda motor yang disebabkan oleh banyaknya jumlah pelanggan yang mengantri karena pendaftaran service masih menggunakan sistem manual.

Sistem manual yang dimaksud ialah jika pelanggan ingin melakukan service kendaraan pelanggan harus datang ke ahass dan melakukan pendaftaran terlebih dahulu kemudian menunggu jadwal service sesuai antrian yang ada.

Untuk mengurangi waktu tunggu peneliti mengusulkan rancangan penggunaan aplikasi SMS Gateway untuk pemesanan service Sepeda Motor di AHASS. Dalam rancangan ini peneliti menggunakan bahasa pemrograman PHP dan MySQ1 serta Software Gammu yang digunakan sebagai alat komunikasi antara aplikasi dengan Modem yang di gunakan sebagai Gateway.

PHP merupakan bahasa pemrograman yang di gunakan untuk membuat aplikasi pemesanan service menggunakan SMS, dimana PHP, HTML, CSS sebagai bahasa 
pembuat kerangka, desain dan pemroses sedangkan MySQL sebagai bahasa pemrograman data basenya [1].

Metode pengembangan sistem yang digunakan adalah Waterfall, Metode waterfall merupakan model pengembangan sistem informasi yang sistematik dan sekuensial [5]. dengan tahapan seperti pada gambar berikut.

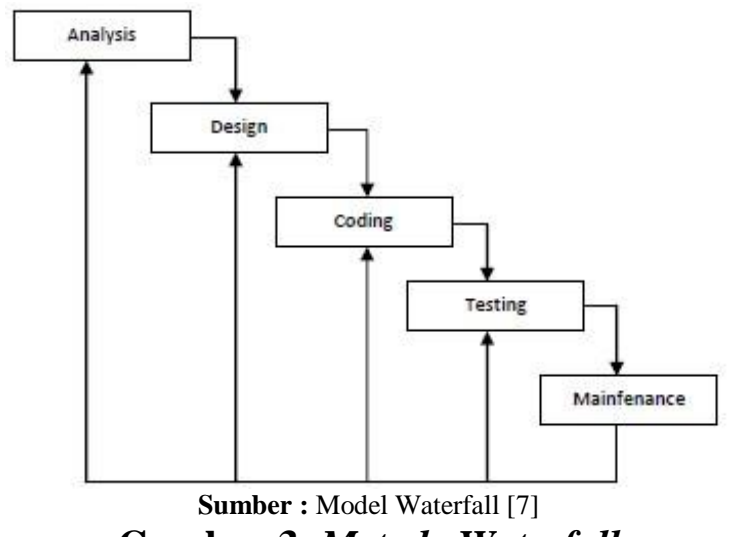

Gambar 3. Metode Waterfall

Tahapan-tahapan dalam metode Waterfall adalah [5]:

1. Analysis, merupakan tahap awal dari pembangunan perangkat lunak, berdasarkan data yang didapat saat wawancara dengan karyawan atau pemilik AHASS, yaitu menetapkan segala hal yang diperlukan dalam pelaksanaan pembangunan perangkat lunak dan menentukan fitur-fitur yang dibutuhkan oleh sistem.

2. Design, merupakan tahap dimana merancang arsitektur, layout tampilan, inputan, output sesuai dengan requirement yang di tentukan di tahap analysis

3. Coding, merupakan tahap penterjemahan dari design kedalam bahasa pemrograman berdasarkan data-data yang telah dianalisa ke dalam bentuk bahasa pemrograman yang sudah di tentukan.

4. Testing, Setelah pengkodean selesai maka akan dilakukan testing / pengujian terhadap sistem yang telah dibuat. Bertujuan untuk menemukan kesalahan atau kekurangan terhadap sistem yang dibuat dan kemudian dapat diperbaiki.

5. Maintenance, merupakan tahap akhir dalam sistem dimana sistem sudah dapat di gunakan dan dilakukan pemeliharaan sekaligus melakukan perbaikan jika timbul masalah pada sistem setelah aplikasi beroperasi.

\section{HASIL DAN PEMBAHASAN A. Analisa Kebutuhan \\ Analisa kebutuhan dilakukan dengan cara wawancara dan observasi ketempat penelitian dengan melihat proses bisnis yang berjalan di Astra Honda Authorized Service Station xyz (AHASS xyz). untuk mendapatkan kebutuhan dalam perancangan system yang akan dibuat, maka peneliti mendapatkan data sebagai berikut :}

\section{Proses Bisnis Berjalan}

a. Setiap Pelanggan yang akan melakukan perawatan sepeda motor dan menjadi member Anggota AHASS perlu datang ke Ahass dan mendaftar terlebih dahulu kepada bagian frontdesk dengan langkah-langkah sebagai berikut:

1) Mendaftarkan diri di bagian frontdesk.

2) Memberikkan data_data diri

3) Petugas mencatat data calon anggota untuk kemudian dibuatkan kartu anggota atau kartu langganan AHASS.

4) Setelah didata dan kartu anggota pelanggan jadi, maka setiap kali melakukan perawatan sepeda motor maka buku dapat digunakan untuk melakukan perwatan sepeda motor yang berfungsi untuk mencatat kegiatan perawatan dan untuk mengetahui perawatan apa saja yang sebelumnya sudah dilakukan. 
5) Pelanggan memberitahukan keluhan yang ada pada sepeda motornya, yang kemudian frontdesk akan mengarahkan pelanggan ke petugas service advisor untuk berkonsultasi dan mendapatkan solusi keluhan sang pelanggan.

b. Proses Melakukan Perawatan

1) Mekanik menerima form work order tentang pekerjaan dan keluhan si pelanggan apa saja yang harus dilakukan terhadap sepeda motor pelanggan.

2) Mekanik mengerjakan form work order.

3) Setelah selesai dikerjakan form work order di kembalikan lagi ke petugas administrasi.

c. Proses pengembalian sepeda motor kepada pelanggan

1) mekanik memberikan sepeda motor yang telah di service kepada petugas final check / kepala mekanik.

2) Petugas final check memeriksa pekerjaan mekanik dan jika pekerjaan dinyatakan bagus atau ok maka petugas akan memberikan informasi kepada petugas administrasi bahwa motor pelanggan sudah dikerjakan dengan baik dan sudah siap di kembalikan ke pelanggan.

3) Bila telah selesai maka petugas administrasi memanggil pelanggan untuk menyelesaikan urusan pembayaran dan mendapatkan kuitansi tanda pelunasan pembayaran perawatan untuk di tunjukan saat pengambilan sepeda motor kepada petugas penyerahan sepeda motor .

d. Proses Pembuatan Laporan

Pembuatan laporan biasanya dilakukan setiap akhir bulan dan laporan tahunan, laporan tersebut berisi sebagai berikut:

1) Data unit sepeda motor perbulan dan pertahun.

2) Data unit kartu perawaan berkala (KPB).

3) Laporan AHASS ke Main Dealer PT. Daya Adira Mustika Sesuai dengan domisili AHASS.

\section{Kebutuhan Sistem}

a. Proses Pendaftaran

Setiap pelanggan yang akan menjadi langganan ahass perlu mendaftar terlebih dahulu kepada petugas frontdesk untuk mendapatkan id pelanggan dan kartu langganan ahass. dengan memberikan data-data diri sebagai berikut:

1) Nama.

2) Alamat.

3) No handphone.

4) No kendaraan bermotor.

5) No STNK

b. Proses Pemesanan Service

Setiap kali seorang pelanggan akan melakukan pemesanan service, proses yang dilakukan adalah sebagai berikut:

1) Pelanggan mengirimkan sms request pemesanan ke ahass dengan format yang sudah di tentukan oleh bengkel Astra Honda Authorized Service Station (AHASS).

2) Frontdesk memeriksa sms pemesanan service pelanggan yang masuk kedalam database sebagai data pemesanan service di AHASS.

3) Aplikasi mengirimkan sms balasan secara otomatis mengenai waktu dan jadwal datang ke AHASS.

4) Frontdesk membuat data laporan pemesanan service manual.

5) Pelanggan datang sesuai dengan waktu yang di jadwalkan.

6) Pelanggan datang 15 menit lebih awal dari waktu yang di jadwalkan. 
7) Setelah datang pelanggan melapor ke frontdesk dan melaporkan pemesanan yang telah dilakukan agar sepeda motor pelanggan dapat di service.

c. Proses Promo AHASS

Frontdesk mengirimkan sms promo kesemua pelanggan yang sudah terdaftar menjadi pelanggan ahass dengan menggunakan data-data pelanggan yang sudah ada dalam database ahass.

B. Desain Sistem

1. Diagram Aliran Data (DAD)

Diagram Aliran Data (DAD), merupakan suatu digram yang mempresentasikan gambaran tentang rancangan yang akan dibuat, sumber data, tujuan data dalam sistem, penggunaan DAD sebagai alat bantu sangat membantu dalam memahami rancangan sistem yang akan di buat atau menjelaskan proses kerja suatu sistem [6]. 


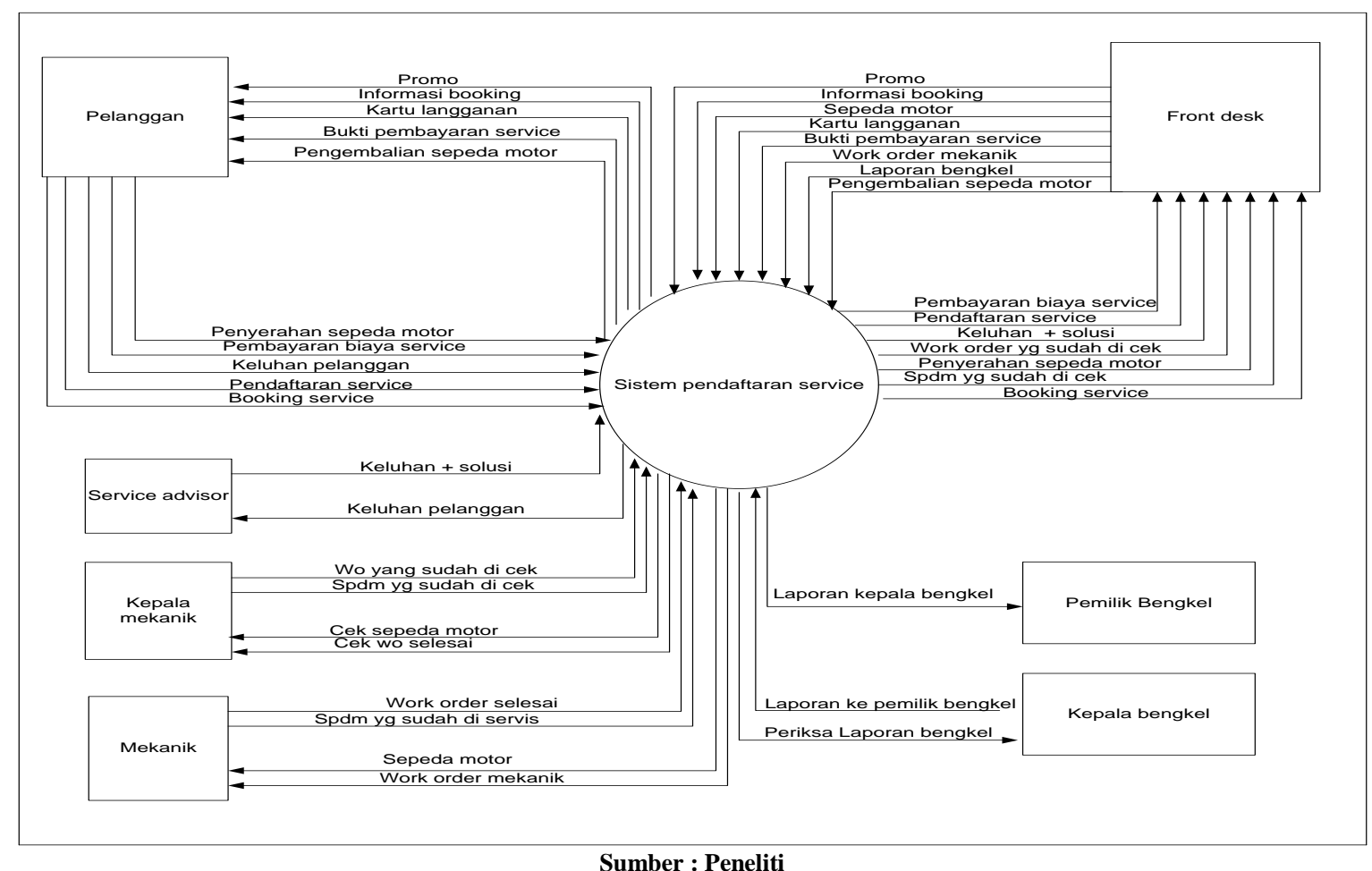

Gambar 4. Diagram Konteks Sistem

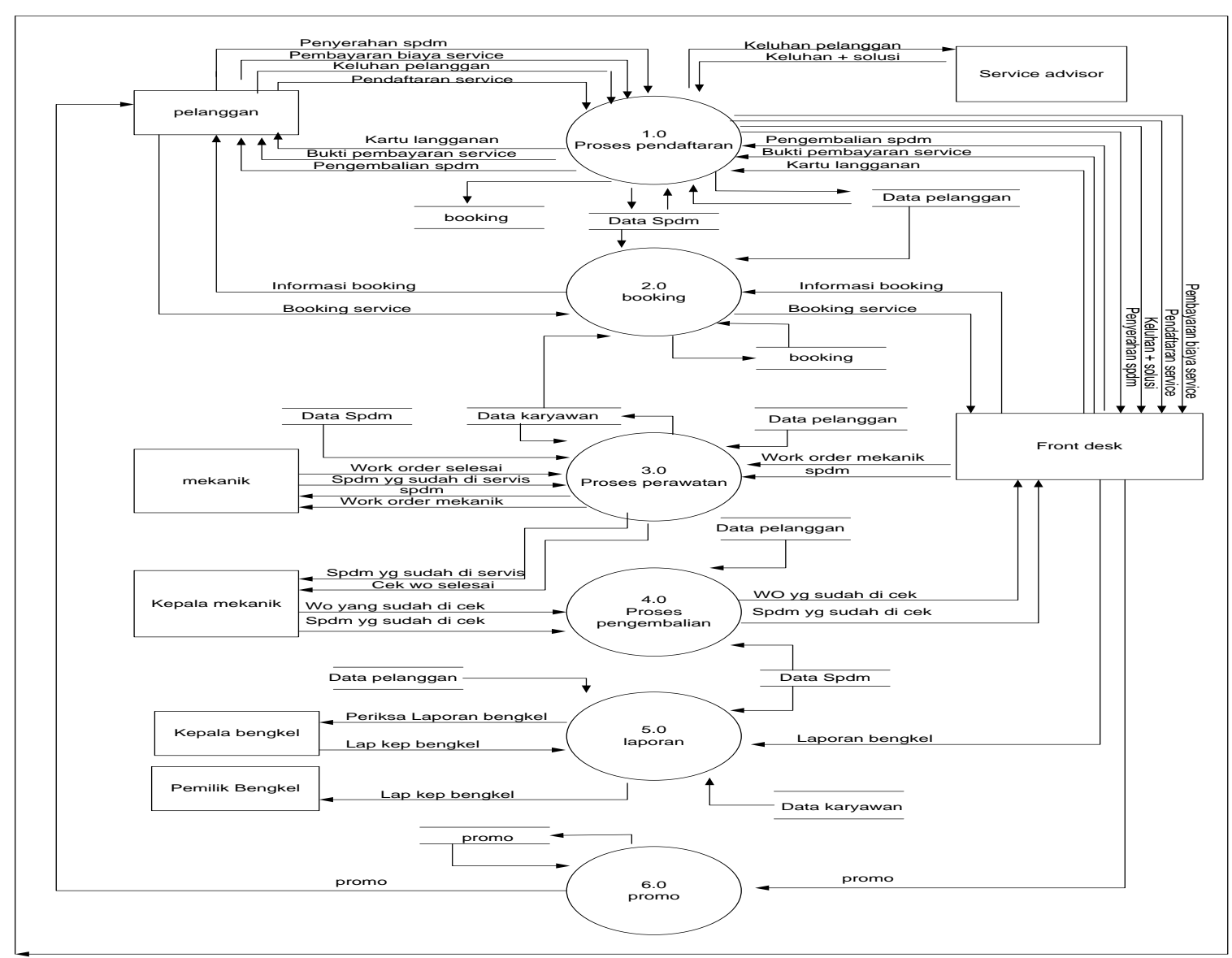

Sumber : Peneliti

Gambar 5. Diagram Nol 


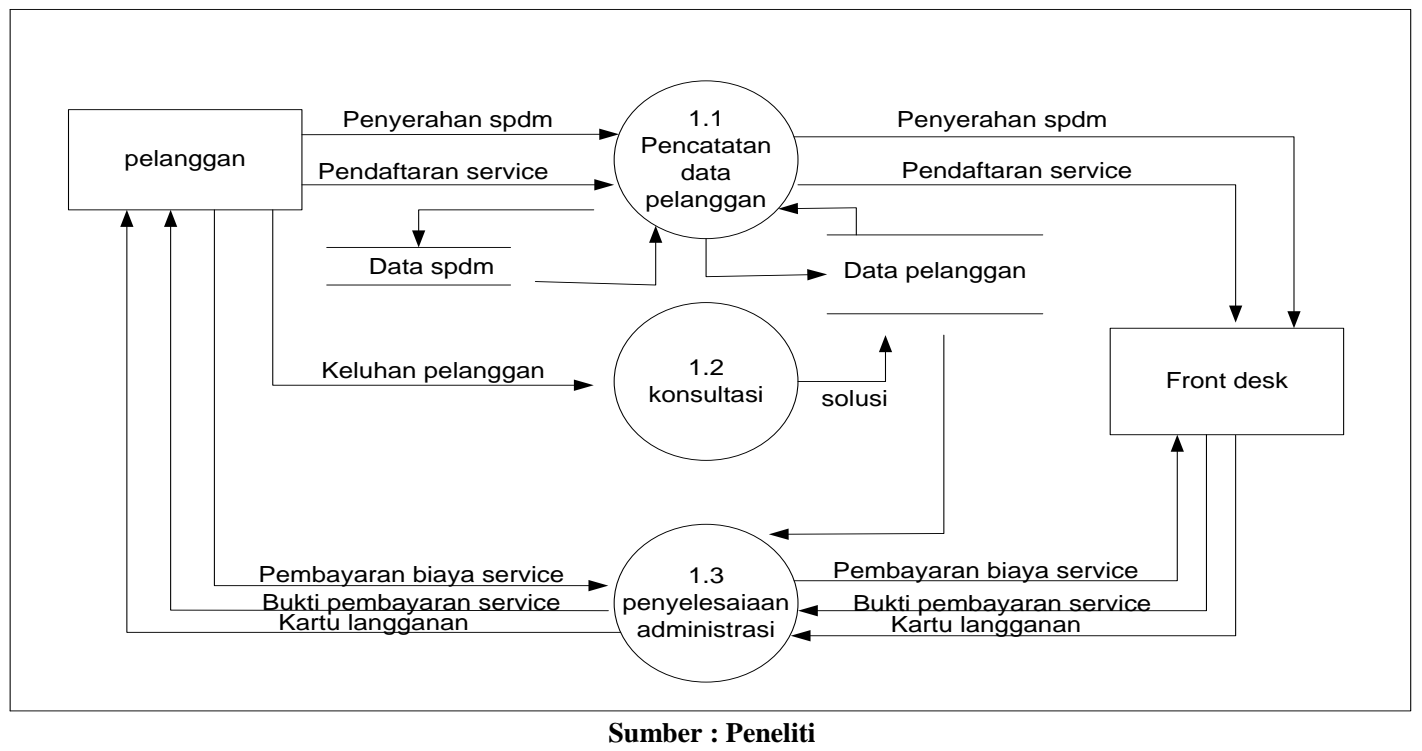

Gambar 6. Diagram Rinci 1.0

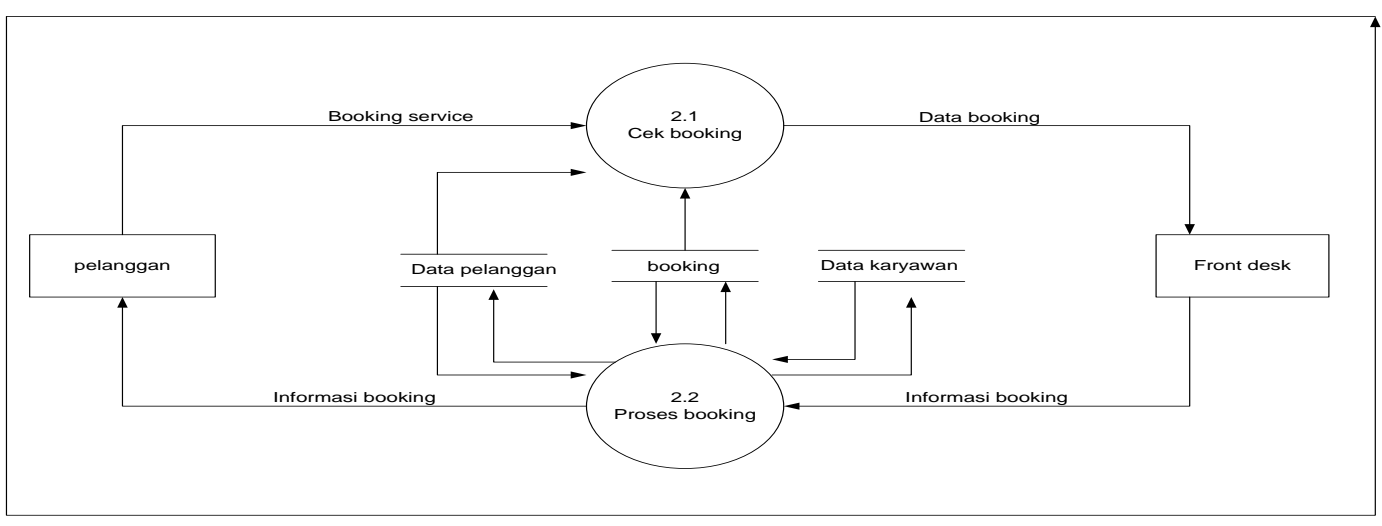

Sumber : Peneliti

Gambar 7. Diagram Rinci 2.0

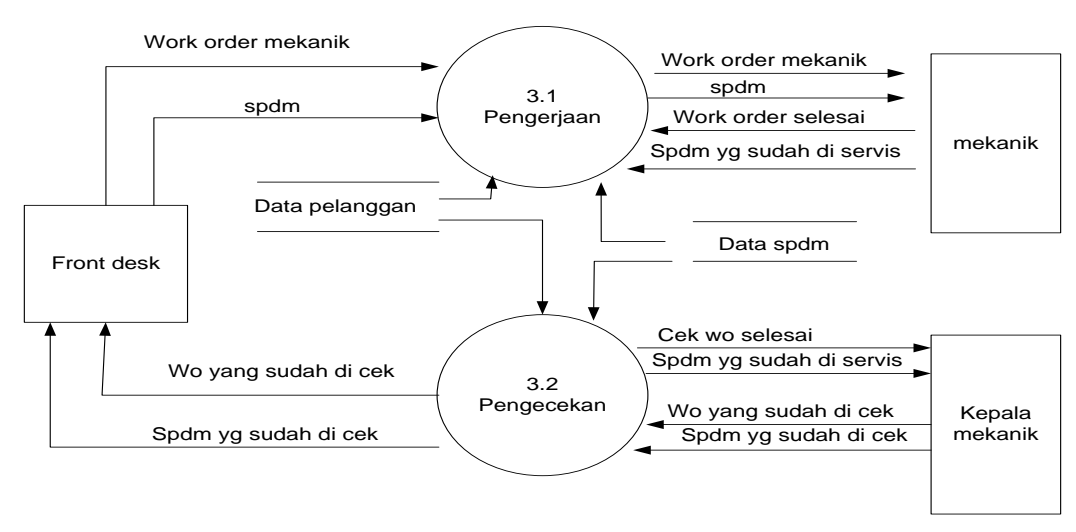

Sumber : Peneliti

Gambar 8. Diagram Rinci 3.0 


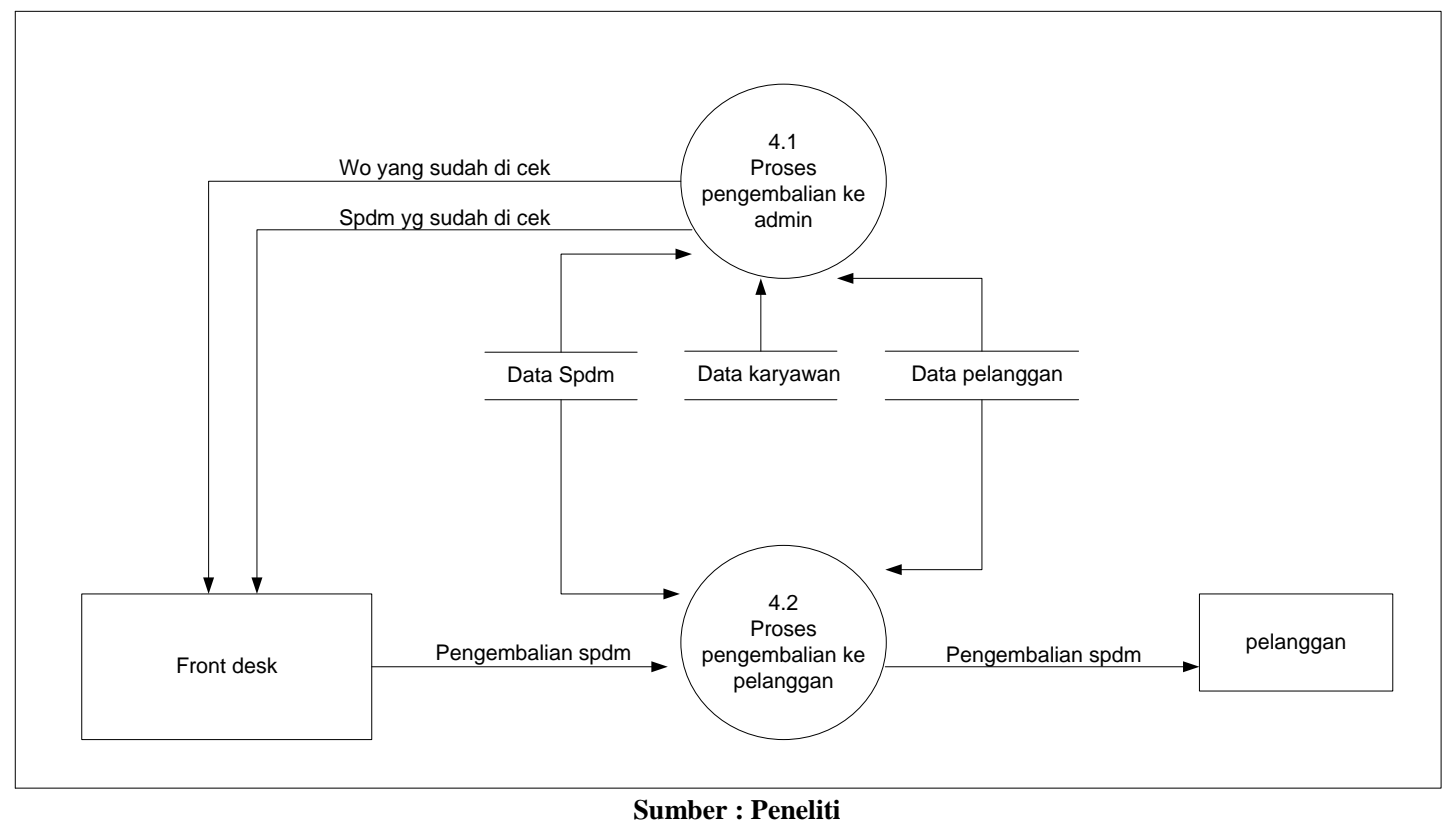

Gambar 9. Diagram Rinci 4.0

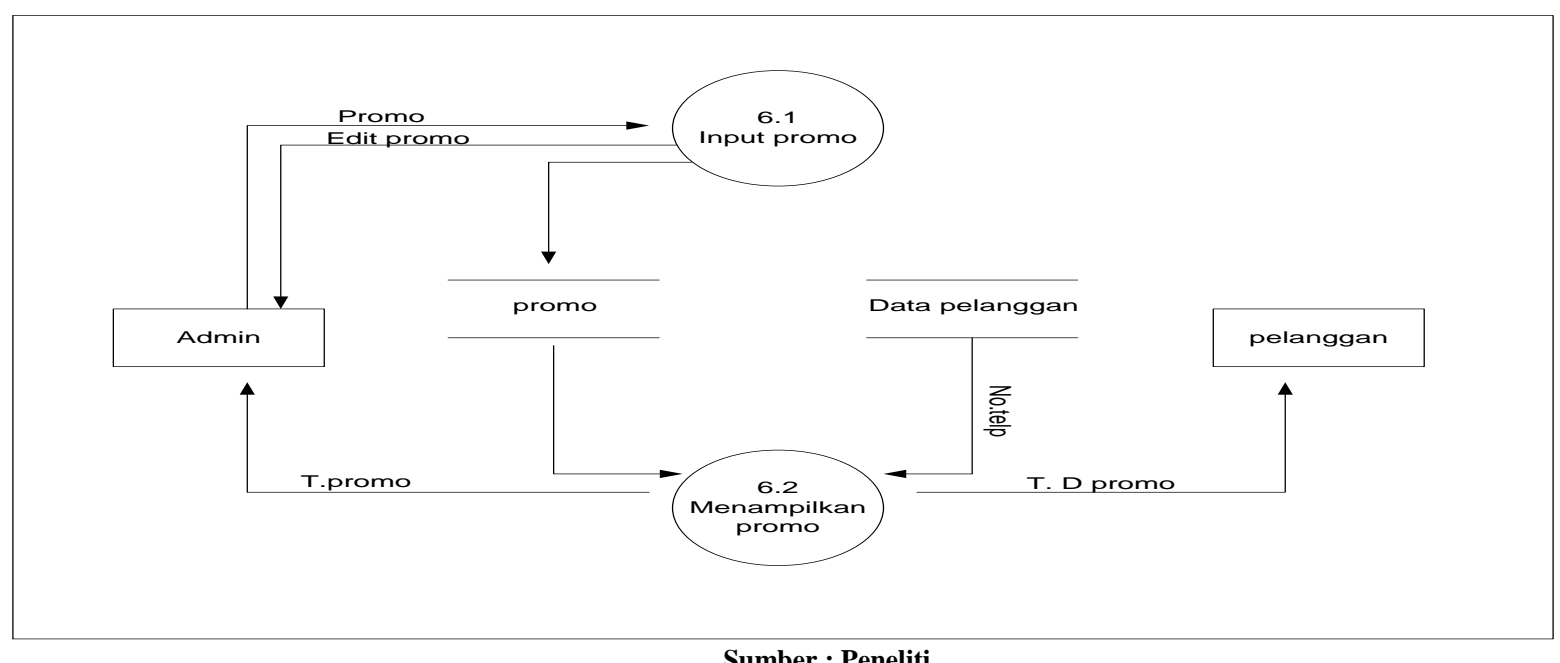

\section{Gambar 10. Diagram Rinci 5.0}

\section{Entity Relationship Diagram}

Menggambarkan hubungan antara satu entitas yang mempunyai satu atau lebih atribut dengan entitas yang lainya didalan sebuah sistem. 


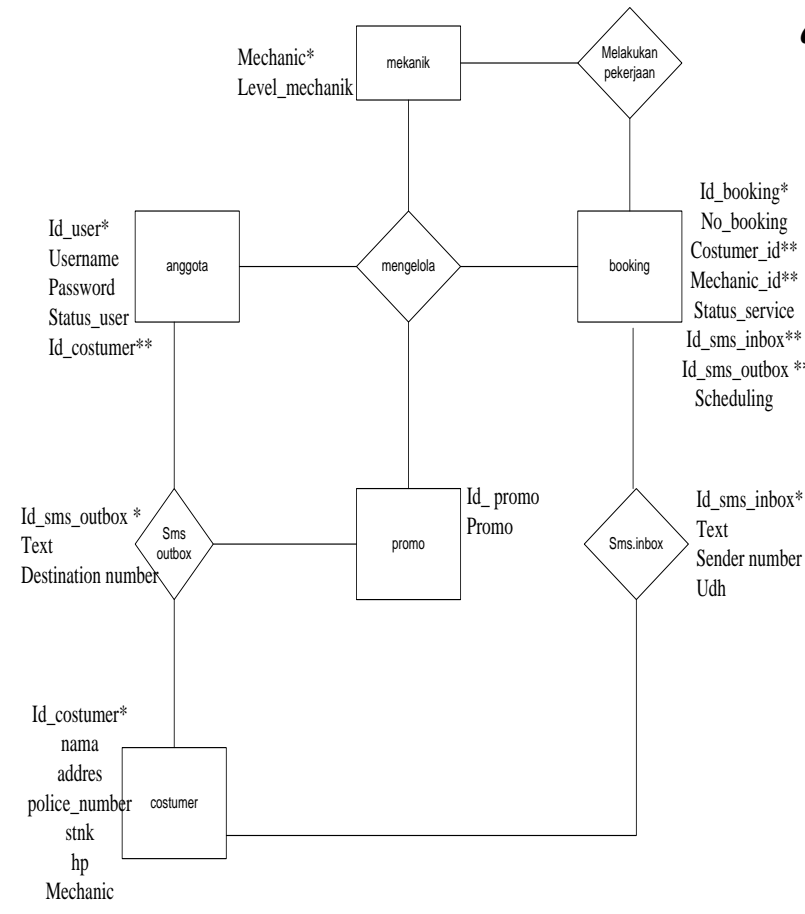

Gambar 11. Entity Relationship Diagram (ERD)

\section{a. Form Login}

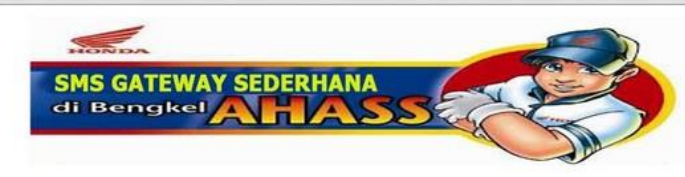

Silakan Login Untuk Masuk
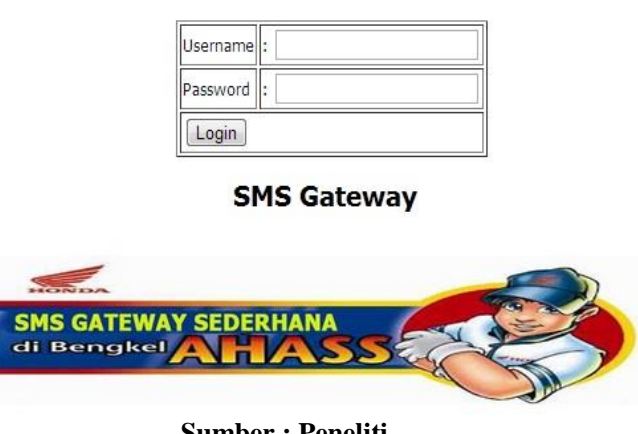

Gambar 12. Form Login

Untuk mengakses atau masuk aplikasi maka di perlukan username dan password yang sudah di daftarkan oleh admin

\section{b. Form Input Data Pelanggan}

Form input data pelanggan untuk memasukan data pelanggan AHASS.

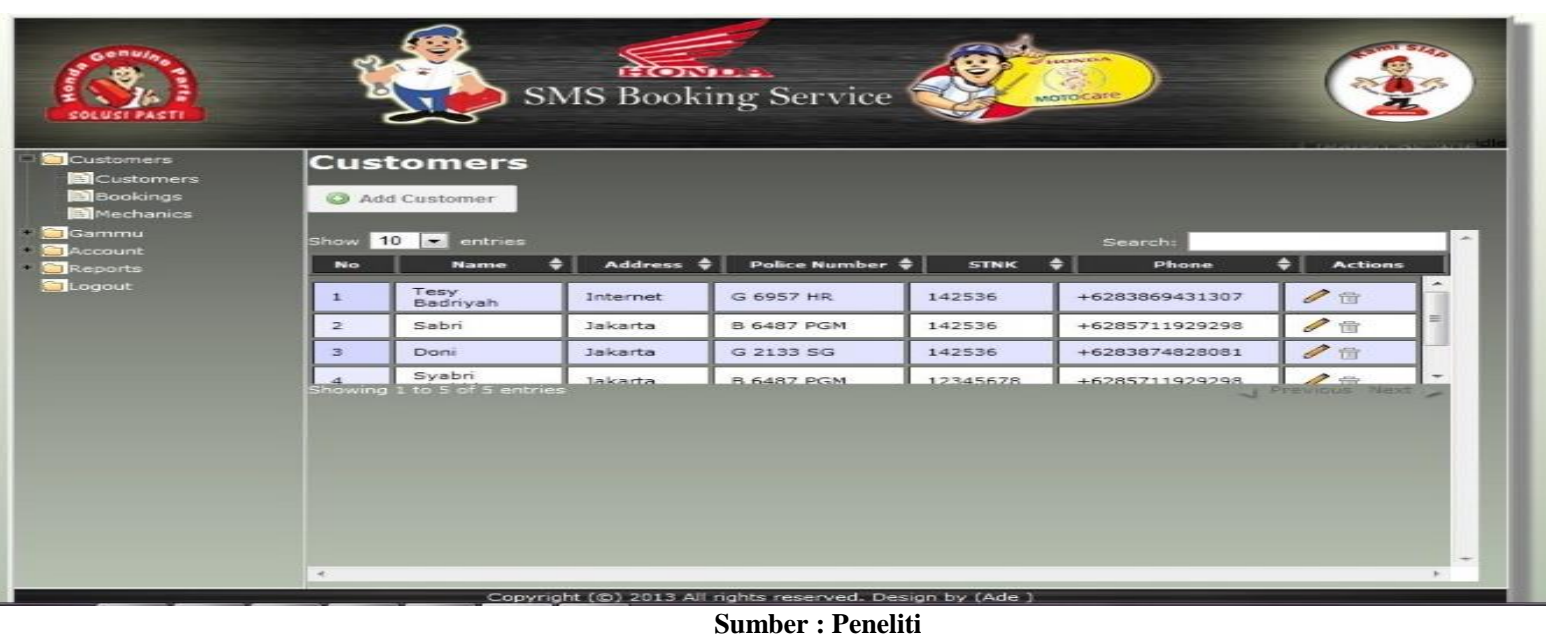

Gambar 13. Form Input Data Pelanggan 


\section{c. Form Booking}

Form Booking berfungsi menampilkan data pelanggan yang booking service via SMS.

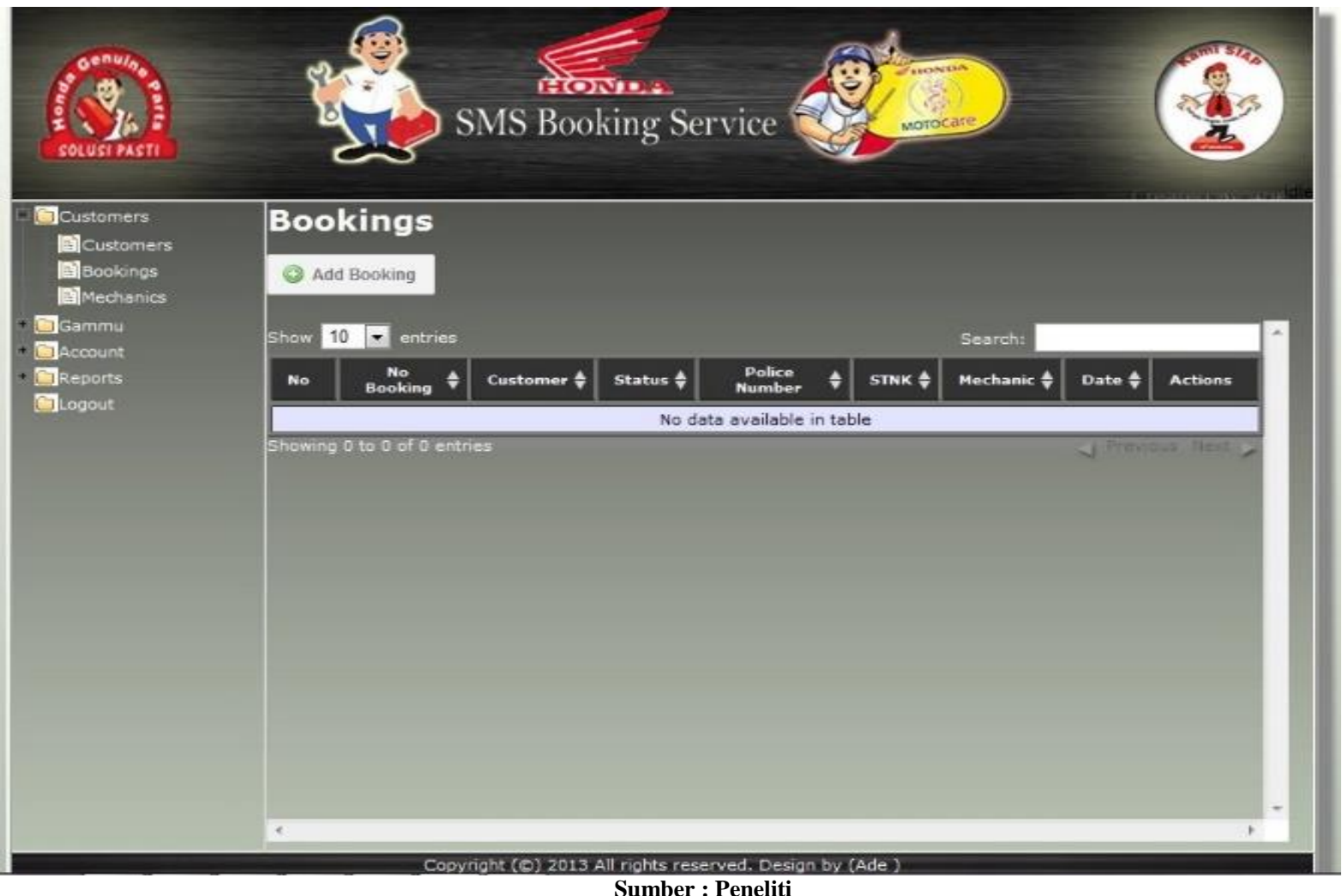

\section{Gambar 14. Form Booking Service}

\section{d. Form Add Booking}

Form Add Booking mendaftarkan booking secara manual dengan kondisi pelanggan telepon langsung ke admin.

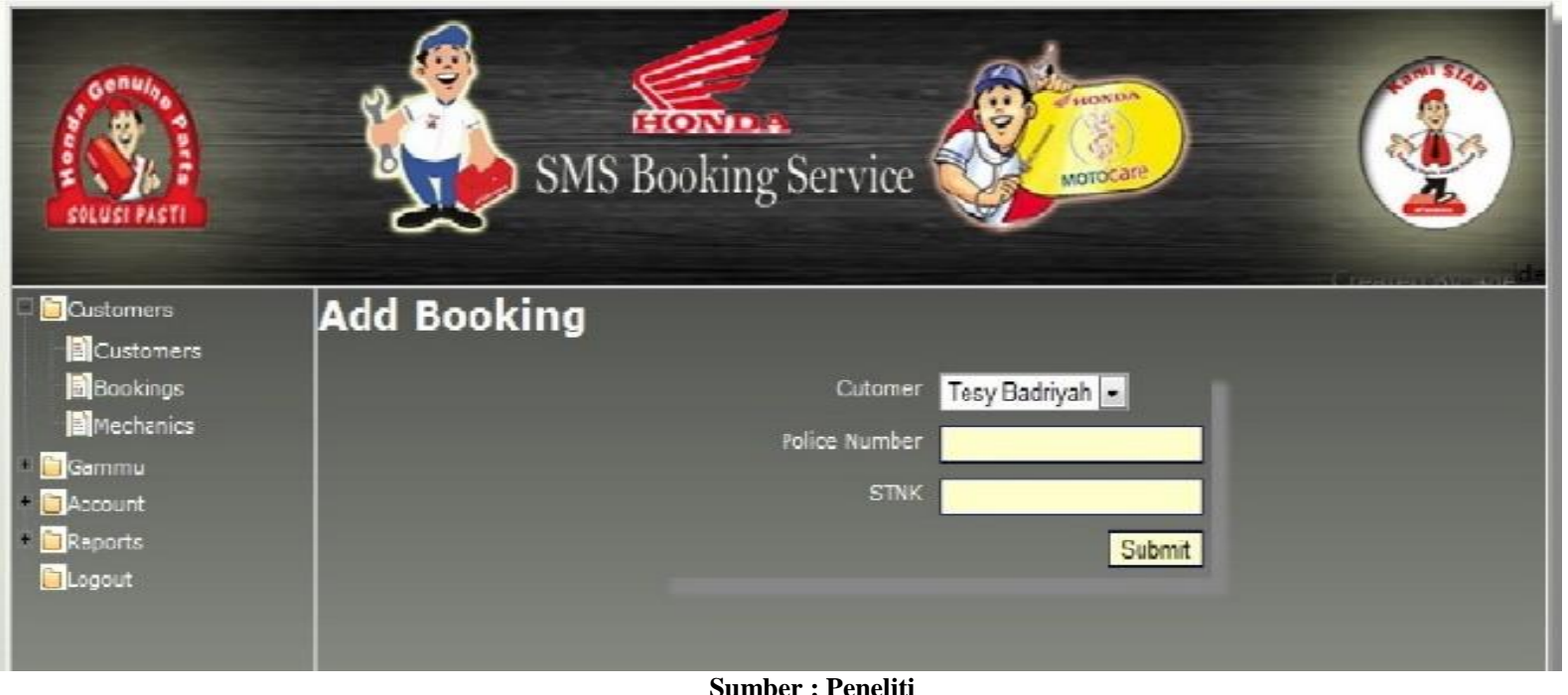

Gambar 15. Form Add Booking 


\section{e. SMS Outbox}

Gambar diatas menunjukan sms balasan yang di lakukan sistem secara otomatis, Fitur sms ini mempunyai banyak fungsi .dalam fitur ini banyak fungsi yang dilakukan secara otomatis baik pemesanan, maupun sms balasan.

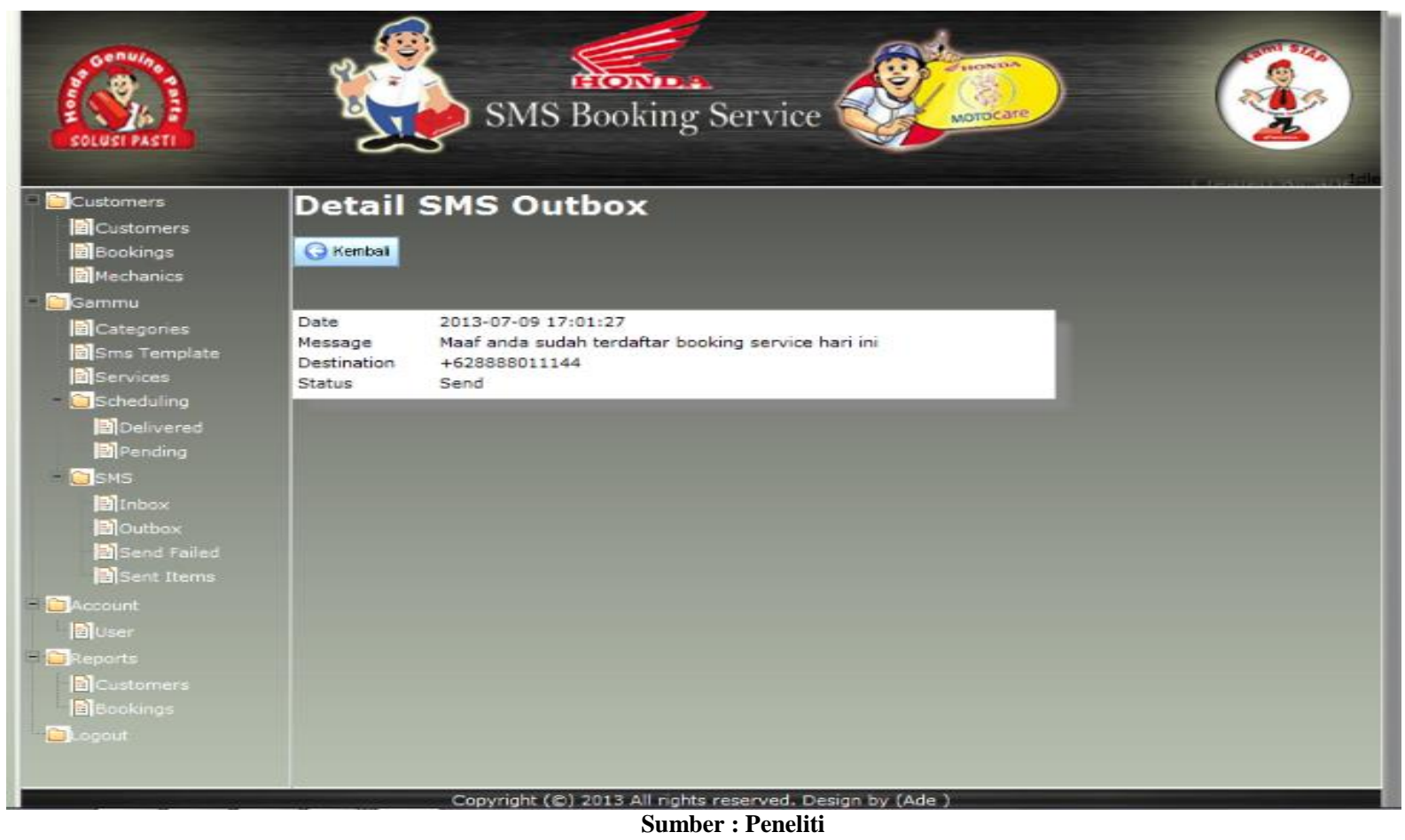

Gambar 16. Tampilan SMS Outbox

\section{f. Form Add Mekanik}

Form Add mekanik berfungsi sebagai input data mekanik, level mekanik.

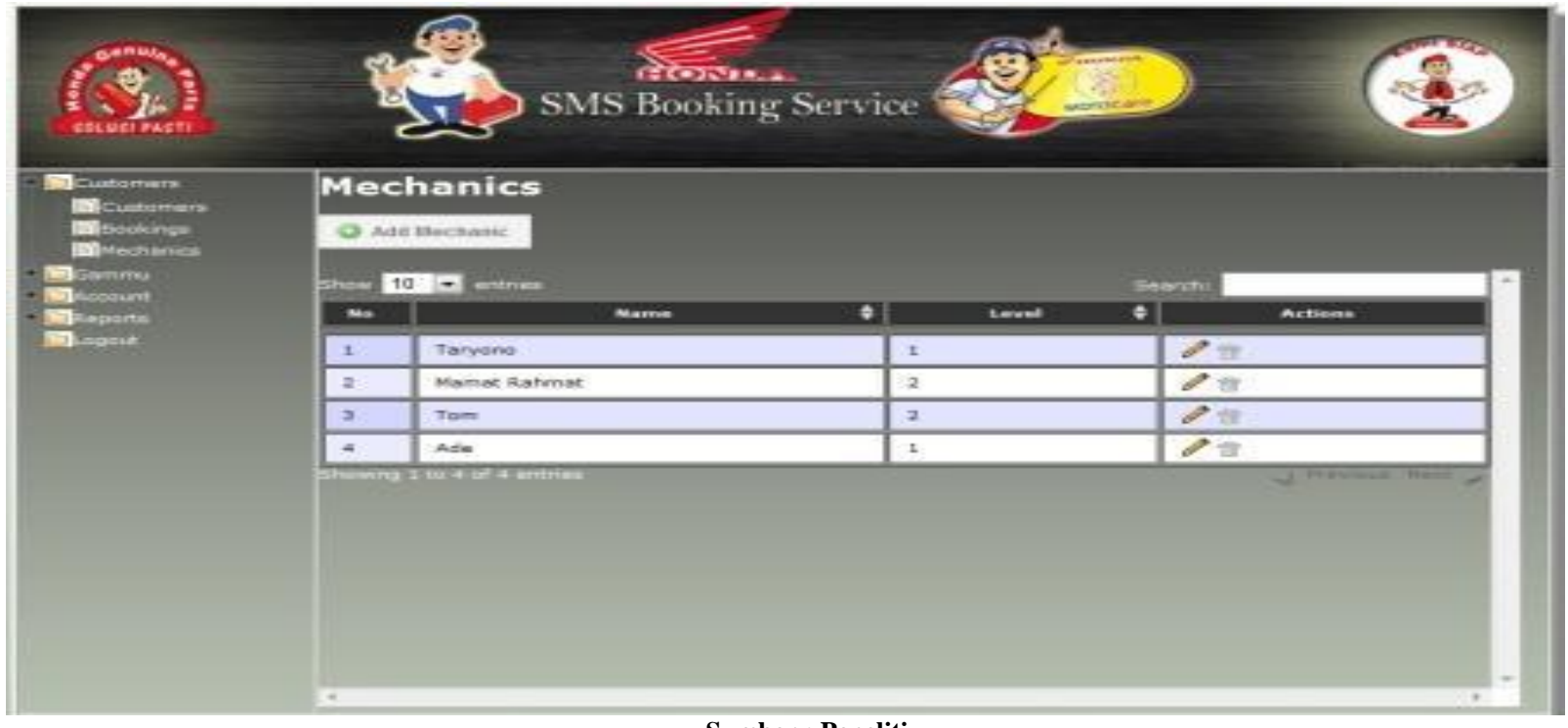

Gambar 17. Form Add Mekanik 


\section{g. Form Promo}

Form promo berfungsi untuk AHASS melakukan sms broadcast kesemua pelanggan ahass atau pelanggan yang dipilih admin. Baik untuk menginformasikan program promo AHASS atau memberitahukan jadwal service pelanggan.

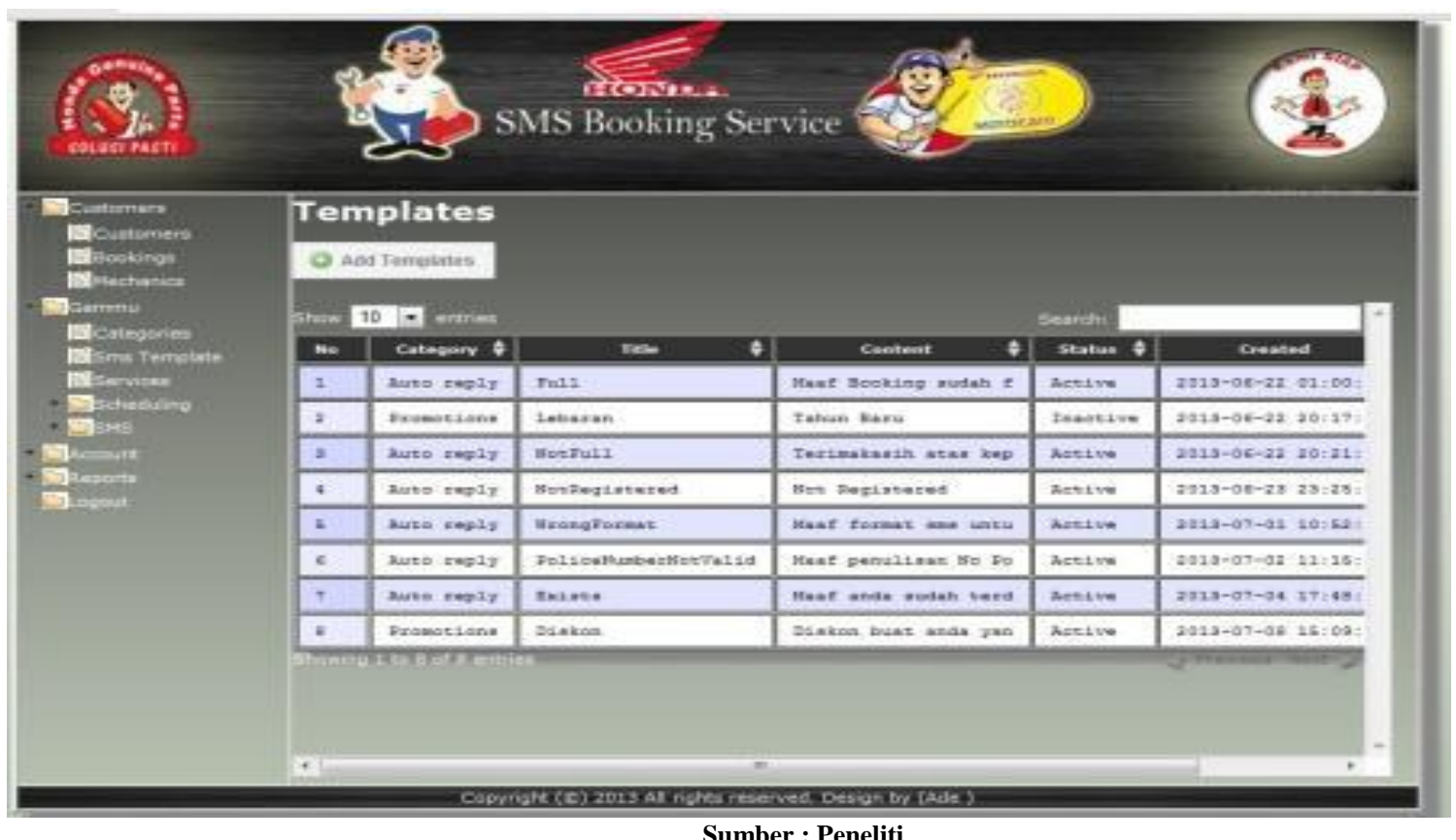

Gambar 18. Form Promo

\section{Pengujian Program}

Pengujian program di lakukan dengan menggunakan pengujian black box dimana pengujian hanya mengamati hasil dari fungsional aplikasi yang dirancang [8].

\section{Tabel 1. Hasil Pengujian Blackbox}

\begin{tabular}{lll}
\hline Fungsi & Pengamatan & Kesimpulan \\
\hline Login & $\begin{array}{l}\text { Input username } \\
\text { dan password }\end{array}$ & Berhasil \\
\hline $\begin{array}{l}\text { Form Add } \\
\text { Customer }\end{array}$ & $\begin{array}{l}\text { Input data, hapus, } \\
\text { update }\end{array}$ & Berhasil \\
\hline Form & $\begin{array}{l}\text { Input manual, } \\
\text { Booking ot omatis by Berhasil } \\
\text { sms, tampilan } \\
\text { booking service, } \\
\text { balasan sms } \\
\text { otomatis, }\end{array}$ \\
\end{tabular}

$\begin{array}{ll}\text { Status } & \text { Ikon berwarna Berhasil } \\ \text { Pemesanan } & \text { merah jika masih } \\ & \text { waktu menunggu } \\ & \text { dan berwarna hijau } \\ & \text { jika sudah di } \\ & \text { proses }\end{array}$

\begin{tabular}{|c|c|c|}
\hline SMS Inbox & $\begin{array}{l}\text { Pesan masuk sms } \\
\text { pemesanan service }\end{array}$ & Berhasil \\
\hline SMS Outbox & $\begin{array}{l}\text { Balasan sms } \\
\text { pemesanan } \\
\text { otomatis }\end{array}$ & Berhasil \\
\hline $\begin{array}{l}\text { Form Add } \\
\text { Mekanik }\end{array}$ & Input data mekanik & Berhasil \\
\hline $\begin{array}{l}\text { Form } \\
\text { Booking } \\
\text { Manual }\end{array}$ & $\begin{array}{l}\text { Input data booking } \\
\text { manual }\end{array}$ & Berhasil \\
\hline $\begin{array}{l}\text { SMS jadwal } \\
\text { service }\end{array}$ & Sms otomatis & Berhasil \\
\hline Form Promo & $\begin{array}{l}\text { Sms } \quad \text { Broadcast } \\
\text { program AHASS }\end{array}$ & Berhasil \\
\hline $\begin{array}{l}\text { Form Report } \\
\text { Booking }\end{array}$ & $\begin{array}{ll}\text { Report } & \text { Data } \\
\text { Booking } & \\
\end{array}$ & Berhasil \\
\hline $\begin{array}{l}\text { Aktifkan } \\
\text { Fitur SMS } \\
\text { gateway }\end{array}$ & $\begin{array}{l}\text { Aktifkan fitur sms } \\
\text { gateway }\end{array}$ & Berhasil \\
\hline Log Out & $\begin{array}{ll}\begin{array}{l}\text { Keluar } \\
\text { aplikasi }\end{array} & \text { dari } \\
\end{array}$ & Berhasil \\
\hline
\end{tabular}

\section{Penerapan Program Dan Maintenance}

Penerapan dilakukan setelah pengujian di lakukan, Peneliti, perangkat lunak di 
jalankan admin dengan sebelumnya di sosialisasikan cara penggunaan fitur yang ada kepada pemangku kepentingan, maintenance dilakukan 6 bulan sekali atau ketika ada permasalahan pada perangkat lunak karena untuk mengetahui apakah perangkat lunak yang dibuat berjalan dengan baik dan fitur yang di sediakan masih sesuai dengan kebutuhan AHASS.

\section{SIMPULAN}

Berdasarkan penelitian yang dilakukan maka disimpulkan Rancangan Aplikasi Sms Gateway Untuk Pemesanan Pendaftaran Service Sepeda Motor menjadi solusi yang baik untuk menyelesaikan permasalahan antrian di Astra Honda Authorized service station xyz (AHASS $\mathrm{xyz}$ ). Dengan fitur SMS gateway yang disediakan unutk mengirim atau menjawab pesan secara otomatis, Pelanggan akan mengetahui kapan waktu yang tepat untuk datang ke AHASS sesuai jadwal yang sudah terecord di dalam database aplikasi ini juga secara otomatis memberikan informasi waktu datang atau informasi jika antrian sudah penuh secara otomatis, ini dapat membuat waktu pelanggan efisien tanpa harus mengantri dan membuang buang waktu menunggu antrian service.

\section{DAFTAR PUSTAKA}

[1] Saputra, Agus dan Agustin, Feni. Membangun aplikasi E-Commerce dan SMS. Jakarta: PT Elex Media Komputindo. 2012.

[2] Saputra, Agus. Membangun Aplikasi Toko Online dengan PHP dan SQL Server. Jakarta: PT Elex Media Komputindo. 2013.

[3] MySQL. (2012, 15 Oktober). Why MySQL? Available: http://www.mysql.com/why-mysql/

[4] J. P. Jumri, "Perancangan Sistem Monitoring Konsultasi Bimbingan Akademik Mahasiswa dengan Notifikasi Realtime Berbasis SMS
Gateway," Informatika, pp. 34- 55, 2012.

[5] Sommerville, I. Software Engineering 9th Edition. Addison-Wesley, 2012.

[6] Basil, Y. A Simulation Model For The Waterfall Software Development Life Cycle. International Journal of Engineering \& Technology (iJET), ISSN: 2049-3444, Vol. 2, No. 5, 2012.

[7] Kristanto, Andri. Perancangan Sistem Informasi dan Aplikasinya, edisi revisi, Yogyakarta: Gava Media. 2008.

[8] A. J. Siddq, A. Budiman, and T. Kurrohman, "Pengujian Perangkat Lunak Dengan Metode Black Box Testing Pada Proses Pra Registrasi User Via Website," Sist. Inf., no. 3211913, pp. 0-8, 2012. 